\title{
RIDING MOUNTAIN NATIONAL PARK - MUSEUM OF NATURE
}

JEWEL THOREN, Riding Mountain National Park, Box 108, Onanole, Manitoba. ROJ $1 \mathrm{NO}$

Riding Mountain National Park, Manitoba is in the central region of North America. Its location and geology contribute to its character. The uniqueness lies in the combination of these factors; all contribute to the meshing of three major ecosystems and therefore to the myriads of species of flora and fauna to be found here.

\section{Landforms and Their Sculpturing}

From west to east the terrain is gently undulating. The eastern edge of the escarpment drops $475 \mathrm{~m}$ to the Manitoba Plains. The bedrock of the Park dates back to the Permian and Cretaceous Periods (Age of the Reptiles). At that time a semi-tropical sea covered much of this area leaving sediment that formed the shale bedrock foundation of the mountains. Fossils of molluscs and reptiles can be found in the ancient shale bedrock formation.

Evidence of volcanic activity is found in the shale of the escarpment. A layer of timealtered volcanic ash (bentonite) occurs. Originating with the mountain-building processes of the Rocky Mountains this ash settled in the area and subsequently hardened and was compressed to about $3 \mathrm{~cm}$ thickness. Bentonite is unstable and can cause landslides or slumping along steep slopes. On Bald Hill landslides have exposed the ochre-coloured bentonite layer.

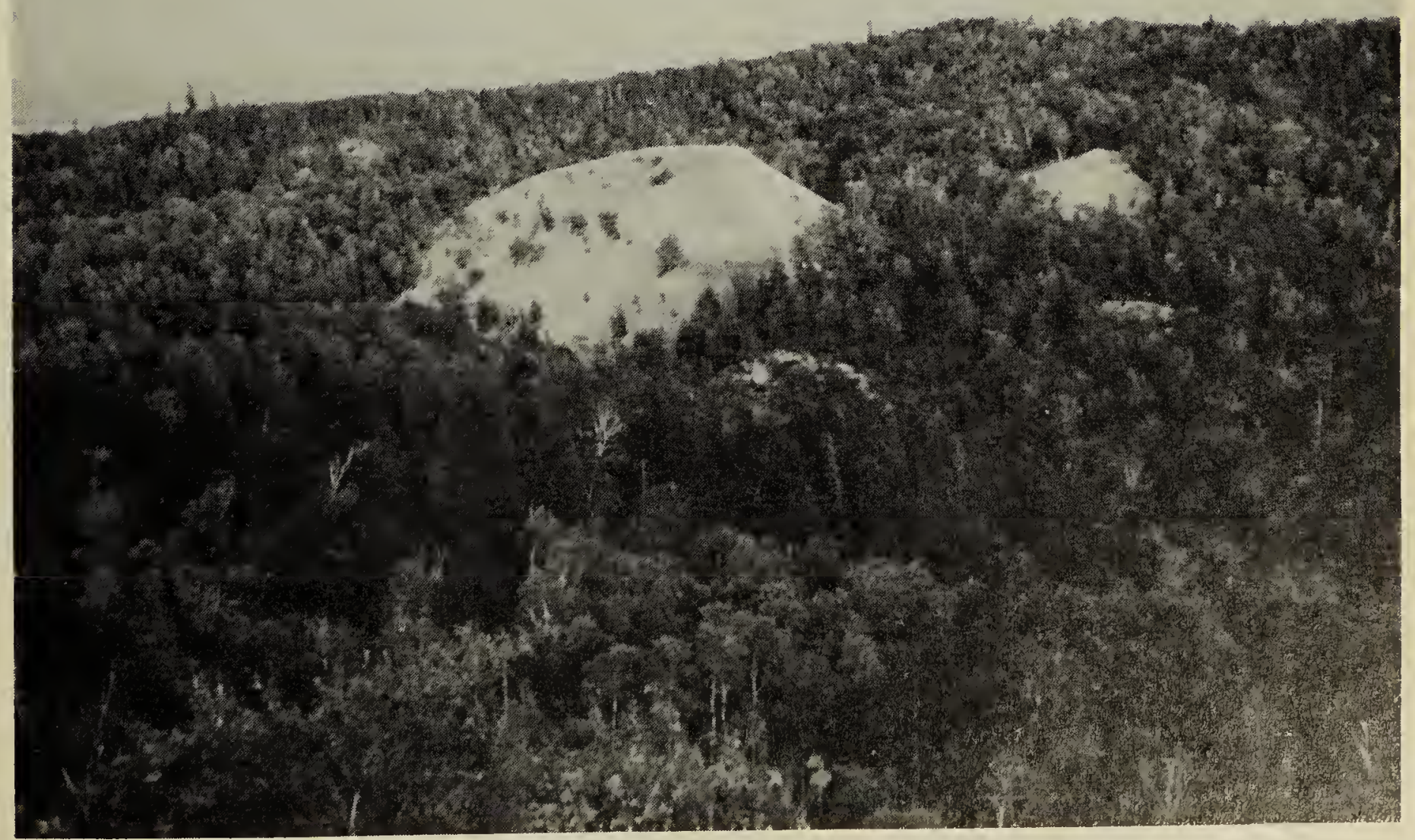


Other layers have contributed to maintaining the face of the escarpment. The caprock of Odanah shale is silica-rich, and more resistant to erosion. The shale beneath is softer and erodes from below until the Odanah shale breaks off. This erosion and collapsing maintains the sharpness of the escarpment.

Debris deposited by the Wisconsin glaciation on the shale bedrock created undulating recessional morainic plains, hummocky knob and kettle terrain, glacio-fluvial channels, rolling terminal moraines and outwash plains. Glacial erratics (granite, basalt, limestone and chert boulders) were brought by the glaciers from the Canadian Shield.

Water and wind erosion has maintained the striking sculpture that is the Escarpment. A great river flowing through Western Manitoba 70 million years ago eroded the bedrock to form its first face. Glacial rivers flowing off the escarpment carved out the notches now cradling the Ochre and Vermilion Rivers. Glacial Lake Agassiz created several beach ridges paralleling the length of Riding Mountain National Park. These can be seen on Beach Ridges Trail at the northern edge of the Park. Rivers flowing into the Glacial lake created fluvial plains which are now rich agricultural land.

Present day erosional forces of frost, rain and flowing water continue to reshape the land. Rivers continue to cut into the shale as they flow off the escarpment.

\section{The Park Today - From West to East}

Riding Mountain National Park from the western grassland to the eastern escarpment supports a rich and varied flora and fauna.

\section{The Western Region}

The Birdtail Valley in the western end of the Park supports a large population of ungulates. Running from Deep Lake to the Sugarloaf Hills, it is especially significant as the winter feeding grounds of the Elk.

The Birdtail Bench and the Sugarloaf Hills support the most easterly distribution of Rough Fescue prairie in Canada. For this

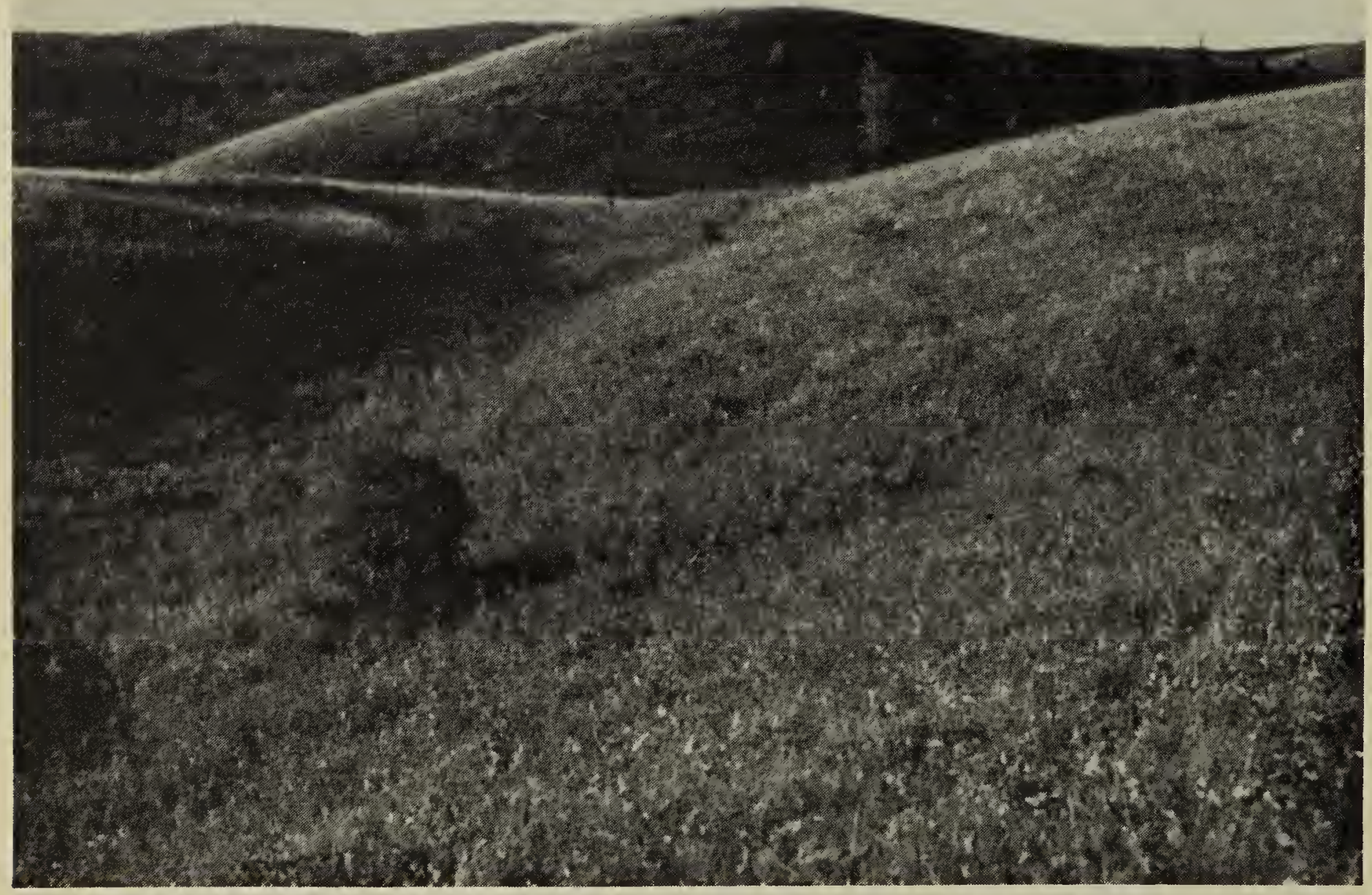

Sugarloaf Hills and Birdtail Valley

R. Walker 


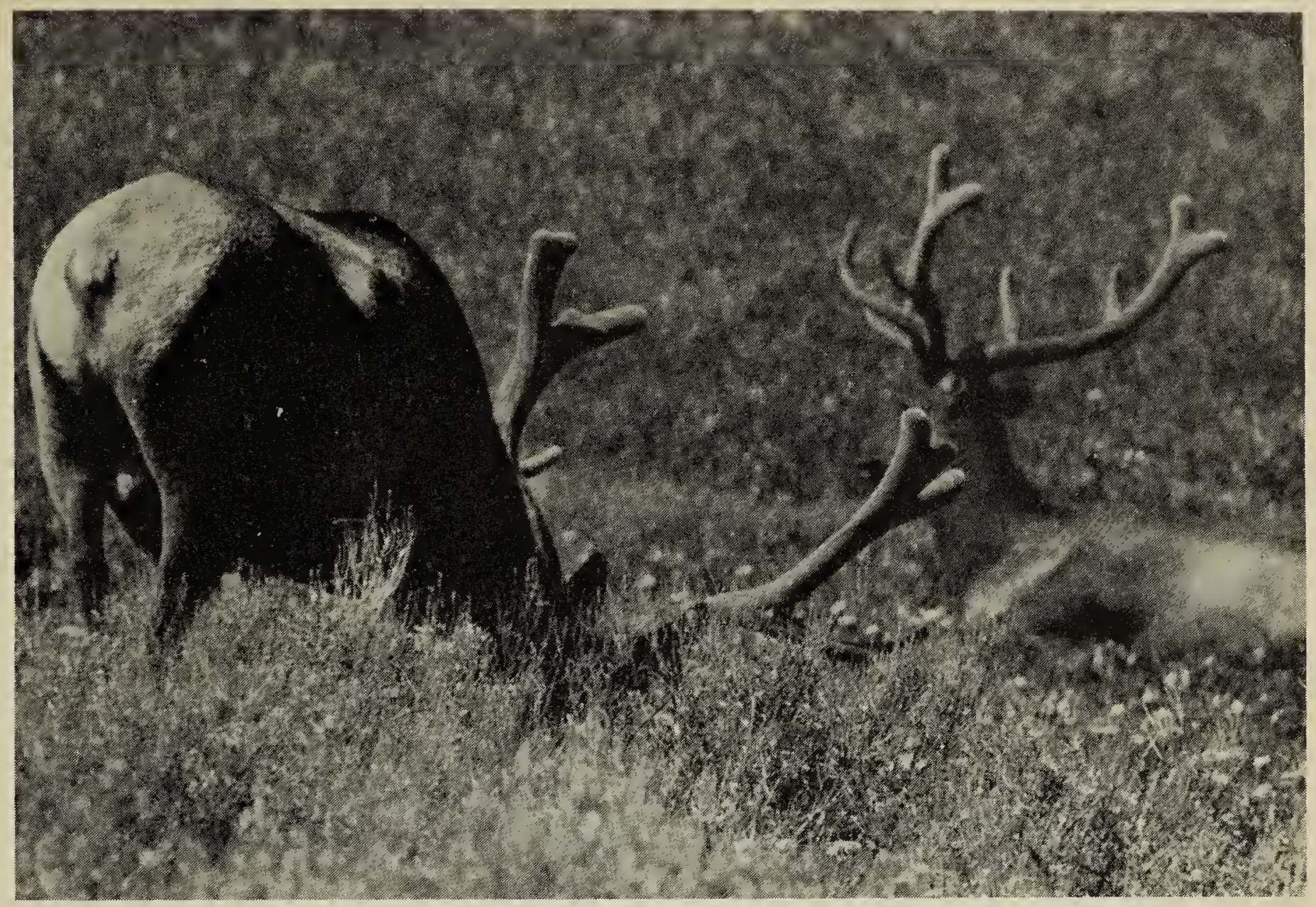

reason the Birdtail Bench was designated as an international biological site by the Canadian Committee of International Biological Programs. Such sites are recognized internationally as requiring special protection because of their biological significance to the world. Moose Lake Forest is a completely intact example of an aspen biotic community. For this reason, it too, has been designated an international biological site.

The beauty of the grassland interspersed with small glacial lakes, Beaver ponds, aspen and spruce is unsurpassed. Rolling hills afford magnificent vistas. You can stand on the Sugarloaf Hills and gaze down on the wide valley with the meandering Birdtail Creek, the remnant of a once torrential glacial river. Turning you will see 80 acres of Rough Fescue prairie. You may catch a glimpse of an Osprey, eagle, or even Cougar.

\section{Lake Audy Area}

Prairie flowers and herbs decorate the rough Fescue grassland edging the quiet waters of Lake Audy. Remnant mature White Spruce stands survived the logging in the area.

A small herd of plains bison graze on the Lake Audy Plain. Driving trails and wheelchair access gives the handicapped person an excellent view of the bison range and exhibits. Interpretive panels include prehistory, history and interesting facts on the ecology of this great mammal, which once roamed freely here before it became an endangered species.

There are three biological sites in the Lake Audy area. Whitewater Lake is a major waterfowl breeding and staging area as well as a major Elk calving area. The region of wet meadows and prairie potholes south of Lake Audy is known throughout North America for its ' waterfowl productivity. Shoal Lake Marsh community is an excellent example of an old lake with typical plant associations of cattail, bulrush and reedgrass. It combines excellent waterfowl and Moose habitat. 


\section{Grasshopper Valley}

Here there is gently knolled land with lovely meadows edged with aspen. In spring, beautiful white blossoms appear deceptively innocent hiding the long, sharp thorns of the gnarled hawthorn bush. Summertime Yarrow, Indian Blanket, Blazing star and yellow-green grasses attract many insects.

In winter, you may see or hear Elk pawing their way to forage beneath the snow. Large poplar and giant spruce interspersed with small meadows and willow make up an oddly mixed wet and dry area. Across the Minnedosa River is a campsite next to gently, rolling terrain along the western edge of the Bison Enclosure.

\section{Strathclair Road}

The Strathclair Road, an old pioneer trail, proceeds north across the park to Vermilion River Warden station. The trail provides scenic views with many open meadows around Kinnis creek. Elk may be seen year round. Vermilion River and Buck Creek host the curious, playful River Otter, a species that is rarely seen in the rest of the park.

Sedge Meadows and Black Spruce

East of Lake Audy are sedge meadows and small basins. There is a great diversity in the age of the mixed boreal forest, through successional transitions, culminating in mature spruce. The upland of mixed boreal forest is dominated by 150-year-old Black Spruce and Tamarack bog. These can also be found in the Boreal Island Trail off No. 10 highway.

\section{The Central Region}

\section{Loons Island}

Loons Island trail meanders along Lake Katherine through stands of Paper Birch and diverse mixed boreal forest. The trail leads out to the lake. You can see a miniature island where loons nest in quiet tranquility. This is one of the few areas in the Park

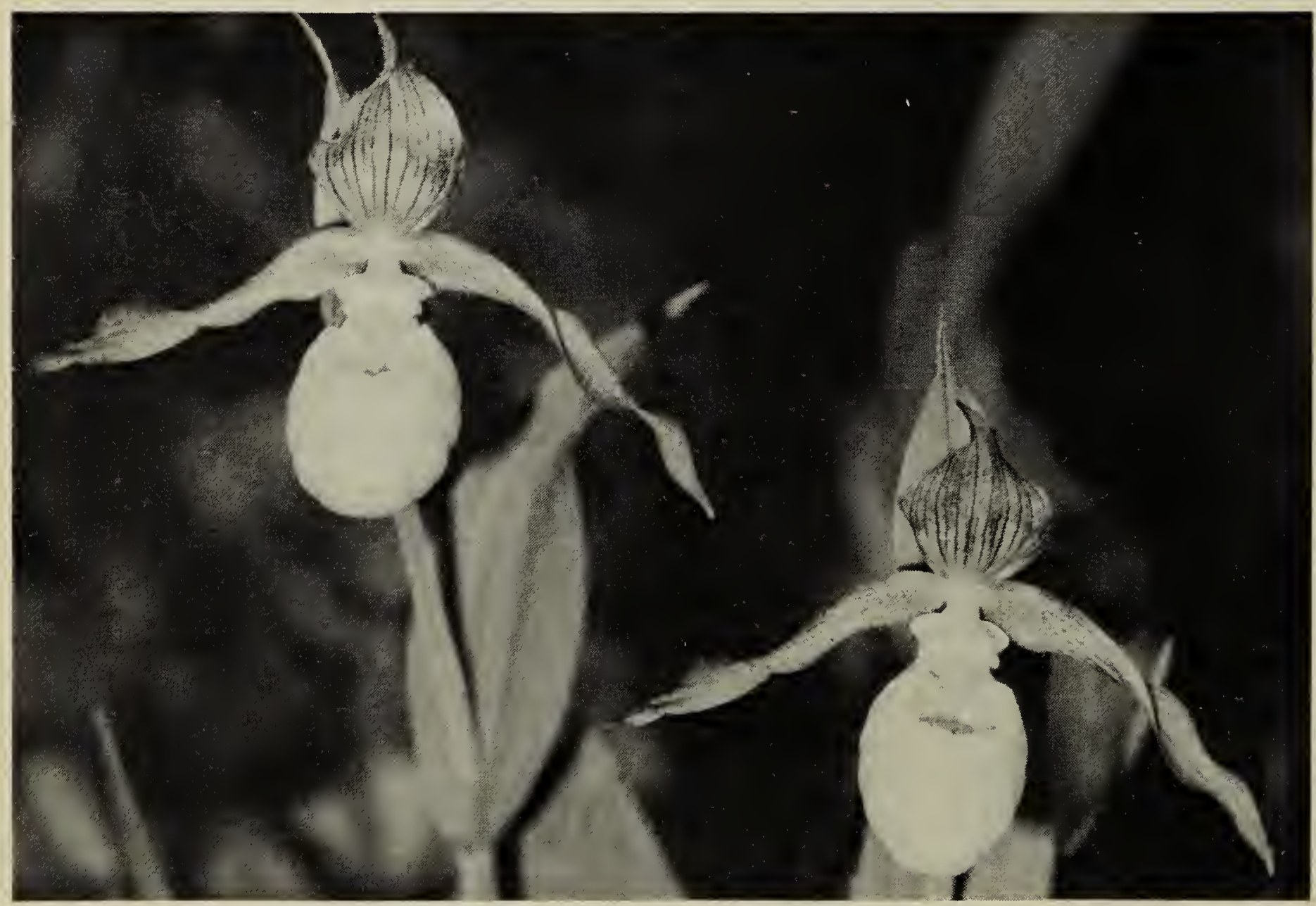


where the delicate blue Kalm's Lobelia can be found. The trail extends through pine, aspen, fir and birch. An understory of Chokecherries, Saskatoons and cranberries all present white blossoms in spring.

\section{Evergreen Trail}

The Evergreen Trail provides a novice hiker with a mini-view of the Park. You will find bog, meadows, spruce-pine forest and aspen woodland. Tiny, delicate, pinkishwhite bells of Twinflower rise above the Sphagnum moss of the bog. You can find Round-leaved Orchis, One-flowered Wintergreen and Labrador Tea. Canada Anemone, Western Red Lily and Hoary Puccoon can be seen in the meadows. You may even see the Yellow Lady's-slipper in the damp woodland. Indian legend tells how a woman ran through the winter snows to bring medicine to her people. She was exhausted, her feet were cut and bleeding from frostbite. She was named Wah-on-nay for her sacrifice. On her death, her foot wrappings became little flowers of yellow known as Wah-on-nay moccasinum or lady's slippers.

\section{The Eastern Region}

In 1980 a fire swept over $194 \mathrm{~km}^{2}$ of the park, blackening some areas and jumping over others. The burning of the thick layer of litter released nutrients for new growth on the bare soil. Regrowth has been rapid. First were Fireweed and asters, brightening the land. Suckering shoots from birch, poplar and shrubs soon appeared. The variety will exceed that of the climax vegetation present before the fire providing the beginning for a rich, new forest.

The intense heat melted the resinous bonds of the many jackpine cones releasing their seeds. Young pines are already up to one metre in height.
The leaves of the deciduous trees didn't burn as easily as the needles of the conifers. Many were scorched rather than killed. Green trees continued to edge the beaver pond off highway \# 19. Here Moose dip their heads beneath the water for submerged plants. Grouse, warblers, deer, Elk and Moose are already moving into the area.

The lookout on \# 19 highway gives you a picturesque view. You can see over the escarpment to the Manitoba Plains. On a hike to Gorge Creek you go down the ravine to the creek. Climbing the other side you view the valley, with a fairly steep trail running through aspen, Balsam Poplar, elm, ash, Mountain Maple, honeysuckle and Wild Plum. There is Ostrich Fern, meadow rue, sedges, bedstraw, and Poison Ivy. If lucky, you may also see bear, Elk, rabbit Coyote, Bald Eagle or even a Cardinal. Along the Oak Ridge Trail by Agassiz Ski Hill there are great oak stands with an understory of hazelnut.

\section{Museum of Nature}

Riding Mountain National Park is a museum of nature preserved intact so our descendants may see what we can enjoy now. Here there are scents and sounds to experience as well as sights. There are no bars for viewing, just wide open spaces where animals and birds wander at will. The pesky mosquito, gossamer-winged butterfIy, Great Blue Heron, tiny wren, shy Lynx, regal Elk, comical bear and the Moose are all present in their natural environment for those who can hike to see.

Hear the sounds, smell the scents, catch the fleeting experiences as in the irridescent sunsets. No artist can resist putting paint to canvas, to try to capture Mother Nature's beautiful works in Riding Mountain $\mathrm{Na}$ tional Park. 